\title{
電子機器の熱設計における機能検証とコンセプト検証 Function and Concept Validation for Thermal Design of Electronic Equipment
}

\author{
○正 横野 泰之（東芝） 久野 勝美（東芝）廣畑 賢治（東芝） \\ Yasuyuki Yokono, Katsumi Hisano and Kenji Hirohata, Toshiba Corp.
}

\begin{abstract}
In order to utilize numerical analysis techniques in the actual design process, not only the numerical analysis techniques themselves, but the procedures for applying those techniques in the design, were examined According to the stage of a design, the example of application of numerical analysis and visualization in the design of an electric equipment was divided into the system performance analysis which drops a product concept on a system function, the layout analysis which determines a system function to a part layout, and the parameter analysis which determines the design parameter of each part. The progress of the numerical technology for product planning is expected. The product development process requires not only numerical simulation based on physics but also statistical approach.
\end{abstract}

Key Words: Design, Electronic Equipment, Numerical Analysis

1.はじめに

電子機器では小型軽量化や処理能力の向上が繰り返され ており，その動作や信頼性を保つかが重要な課題となって いる.また, 電子機器の開発サイクルは短く, 設計が固ま った後に対策を行うことでは製品開発のスピードに対応で きず，より効率的な設計が求められている。このような背 景から，開発の効率化を目的として設計への数值解析の取 り込みには大きな期待がかけられている，ここでは，数値 解析の利用技術を設計の段階によって分類して, 電子機器 の熱設計における数值解析の適用例を紹介し，その現状と 課題について述べる.

\section{2. 製品開発プロセス}

図 1 に電子機器における製品開発プロセスの概要を示す. マーケットの要求や新技術の登場によって, 製品のコンセ プトが生まれる.これからシステム機能, 部品レイアウト, 部品パラメータを決めていく作業を製品開発とする．上述 の順序にブレークダウンしていくことを設計(design)と呼 び，逆方向に想定した機能が実現されているかの確認を検 証(verification)と呼ぶことにする. システム機能が容易に想 像できたり，部品の詳細パラメータ選びに余裕がある場合 は，検証は設計者の頭の中で行われる．システム機能に余 裕が無く，それを容易には想像できない場合は実験などに よる検証が必要になる。一度でシステム機能を満たせばよ いが,通常この設計と検証が繰り返して行われる事が多い. 設計に数值解析を適忘するのは，この検証を勘や実験から 数值解析に置き換えようとするものであり, 設計と検証の 繰り返しのコストを下げ，開発の速度を上げることが目的 である．数值解析は検証を行う技術であり，設計との繰り 返しがあってはじめて開発の効率化に寄与する(1).ここで は，上述の製品開発プロセスの各段階に分けて，数值解析 の利用技術を考えてみる.

\section{3. 数値解析事例}

3.1 パラメータ検証

電子情報機器における部品としては半導体パッケージや 冷却フィン, ファンなどであり，寸法が小さく比較的低流 速で用いられることから, 定量的な数值解析が可能となっ ている. 冷却用ファンの解析により, ファン内部での圧力 分布が得られ，翼形状が剥離域に及ぼす影響などが検討で きる(2).このように，この段階では，解析結果の定量的な 検討や速度, 圧力, 温度といった物理量の詳細な観察から
設計改良のヒントを得ることができる．さらに，最適化手 法と数值解析の組み合わせによる設計案の算出や設計パラ メータの変動によるロバスト性検討なども行われており, 数值解析が有効な手段となっている.

\section{2 レイアウト検証}

部品のレイアウトを決めるようなシステム全体を対象と した例としてはノートPCの解析結果 ${ }^{(3)}$ などがある。この例 では, 詳細なCADデータを用いて詳細な解析を実施するの ではなく，ある程度ラフな解析モデルに変換している．解 析の結果による形状変更やレイアウト変更は構造設計など 他の設計にも影響を与えるので, このラフなモデルでの設 計変更は詳細なCAD情報そのものに反映される必要があ るが，自動的にフィードバックすることは困難で，人の手 を介してCADデータを変更している．このように，システ ム全体を対象とした解析では，様々な内蔵部品を取り替え るなどの柔軟なレイアウト変更には対応不十分な点があり, モデル構築技術に関しては進展を期待したい. また, 定量 性の向上や部品ごとの詳細な設計パラメータ表現が可能に なれば新たな用い方が広がり，CADデータへのフィードバ ックも可能となる. これらは, 解析モデルの大規模化や解 析の高速化の進展に期待するところが多く, 現時点でも一 部は実施可能であり,将来には実現されると考える。

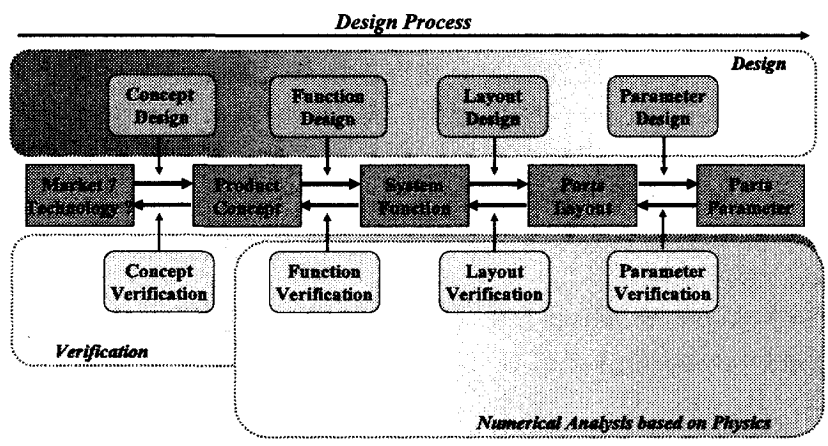

Fig.1 Product development process

\section{3 機能検証}

この段階では，製品コンセプトからシステムでの機能が どのようになるべきか，あるいはならざるを得ないかを決 定する. 電子機器では，ある発熱量のCPUをどのくらいの ファンで冷却するか，その際に筐体の大きさや重量はどの 
ようにすべきか，また，バッテリー持続時間との兼ね合い はどのようにするかといったような様々な機能を決める段 階といえる。多目的最適化を用いたパワーユニットの設計 例 ${ }^{(4)}$ を図 2,3 に示す. パワーユニットでは, 素子の温度を 所定の值以下に保つのみではなく，熱膨張差による歪の低 減や冷却に必要な送風機の低圧力損失と低騒音, さらには 機器の小型化を同時に満たしていく必要がある。これに対 态するため, あらかじめ熱伝導解析などにより求めておい た設計パラメータと各目的関数の関係を基に，遺伝的アル ゴリズム(Genetic Algorithms)による多目的最適化を実施し たものである。目的関数のトレードオフ関係が分かると共 に，ある評価基準の值を改良するためには残りのどれかの 評価基準の值を改悪しなければならない解，すなわちパレ 一ト解が得られた。機能検証には，電気的特性や使いやす さ, 製品全体での騒音, 品質感など解析困難な指標間での トレードオフを調べることが求められたり、まったく新し い概念が生まれてきた時にどのような性能を発揮するかを 定量的に把握するといった要望もあり，今後の進展を期待 したい.

\section{4 コンセプト検証}

これまでの検証は物理現象に基づく数值シミュレーショ ンによって行った．製品コンセプトを検証するにはこのよ うな数值シミュレーションは適さない，ここでは，統計手 法を用いて，ノートPCを対象として，販売台数に及ぼす CPU性能やHDD容量といった機能と販売価格および意匠 デザインなど官能指標の関係を定量化した例 ${ }^{(5)}$ を図 4,5に 示す. 用いた手法は，実際の販壳台数，価格を基にした共 分散構造モデリング, モンテカルロシミュレーション,ニュ 一ラルネットによる回帰である. 実際の販売デートを基に して，ノートPCの価格，スペック，官能性能から販売台数 を推定する回帰モデルを作成し，このモデルにより，仕様 を変化させた際の販売台数の違いや，販売台数が変化しな いような価格差について検討することができた。 この段階 の解析例はほとんど見られず，事例の増加が望まれる.

\section{4.おわりに}

数值解析の利用技術を製品開発の段階によって分類して, 電子機器の設計における数值解析の適用例を紹介した．部 品レベルのパラメータ検証やシステム全体を対象としたレ イアウト検証は様々な解析例があり，普及してきている. 製品のシステム機能を検討するための新たな解析手法や最 適化，可視化技術の進展が期待される. 製品のコンセプト を考える場合には，物理現象に基づくシミュレーションの みではなく統計手法も必要になり，今後、解析事例が増加 することが期待される.

\section{5 . 参考文献}

(1) Yokono, Y., Hisano, K. and Ishizuka, M.,Thermal Science and Engineering Vol.8, No.1, (2000), pp.39-45

(2) Biswas, D., Yokono, Y. and Iwasaki, H., Proc. of International Symposium on Micro-Mechanical Engineering, 200-207, (2003)

(3) Hisano, K., Iwasaki, H. and Ishizuka, M.,Thermal Science \& Engineering, Vol. 5, No. 2, (1997), pp.7-12.

(4) 横野ほか, 可視化情報学会論文集, Vol.24, No.10, (2004), pp.49-54

（5）横野ほか，可視化情報シンポジウム，(2007)

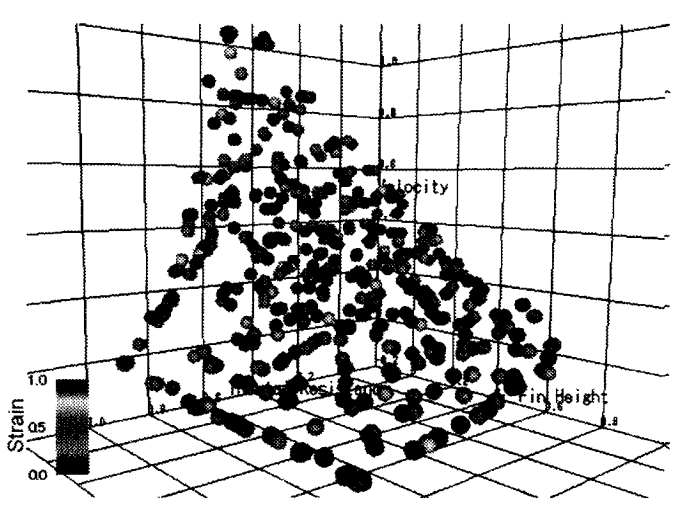

Fig.2 Multi objective optimization

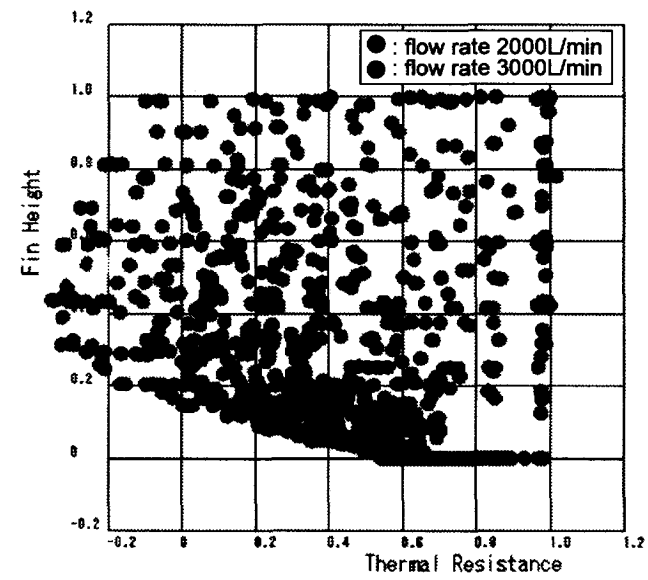

Fig.3 Effect of flow rate limit

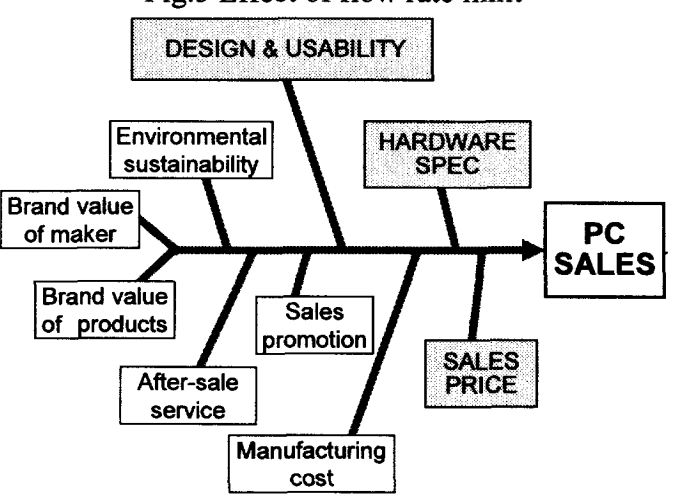

Fig.4 Parameters on PC sales

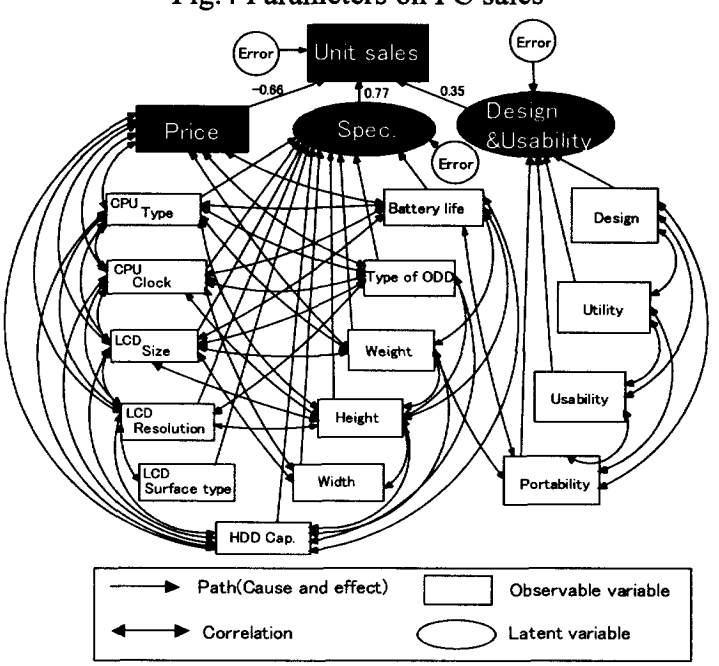

Fig.5 Structural equation modeling 